\title{
Particle Films Affect Carbon Assimilation and Yield in 'Empire' Apple
}

\author{
D. Michael Glenn ${ }^{1}$ \\ U.S. Department of Agriculture, Agricultural Research Service, Appalachian Fruit Research Station, 45 \\ Wiltshire Road, Kearneysville, WV 25430
}

Amnon Erez ${ }^{2}$

Institute of Horticulture, ARO Volcani Center, box 6, Bet Dagan, Israel 50250

Gary J. Puterka ${ }^{3}$

U.S. Department of Agriculture, Agricultural Research Service, Appalachian Fruit Research Station, 45 Wiltshire Road, Kearneysville, WV 25430

\author{
Patricia Gundrum ${ }^{4}$ \\ U.S. Department of Agriculture, Agricultural Research Service, Appalachian Fruit Research Station, 45 \\ Wiltshire Road, Kearneysville, WV 25430
}

\begin{abstract}
AdDitional INDEX words. Malus $\times$ sylvestris var. domestica, heat stress, whole canopy photosynthesis, isotopic carbon discrimination, light scatter, kaolin, calcium carbonate

Abstract. Processed-kaolin particle films (PKPFs) are used commercially in large quantities on horticultural crops to repel insects, and reduce heat stress and solar injury of fruit. Our studies determined the effect of two processed-mineral particle film materials (kaolin and calcium carbonate), on whole plant carbon assimilation, water use efficiency, yield, mean fruit weight and quality in 'Empire' apple [(Malus xsylvestris (L.) Mill var. domestica (Borkh Mansf.))] over a four-year period. The application of a PKPF reduced canopy temperature, and probably reduced environmental stress, resulting in increased mean fruit weight and red color in two of the four years of the study. Whole canopy carbon assimilation studies indicated increased carbon assimilation only under conditions of high air temperature. The PKPF sprayed leaves also had reduced water use efficiency; likely due to increased stomatal conductance associated with reduced leaf temperature. Calcium carbonate had none of the positive effects of PKPF and reflected more photosynthetically active radiation $(P A R)$ than the PKPF.
\end{abstract}

Processed-kaolin particle films (PKPFs) are used in horticultural crops to repel insects (Glenn et al., 1999; Knight et al., 2000; Puterka et al., 2000; Showler, 2002; Unruh et al., 2000), suppress disease incidence (Glenn et al., 1999; Glenn et al., 2001a; Puterka et al., 2000) and reduce heat stress and solar injury (Glenn et al., 2001b, 2002; Jifon and Syvertsen, 2002; Tworkoski et al., 2002). The presence of mineral particles on the leaf surface can reduce the amount of photosynthetically active radiation $(P A R)$ reaching the leaf surface by reflecting $P A R$ from the canopy and reducing net carbon assimilation $\left(\mathrm{A}_{\mathrm{CO}_{2}}\right)$ in the plant canopy. Glenn et al., (1999) demonstrated that the particle film does reduce $P A R$ transmission $\approx 10 \%$, yet apple [(Malus $\times$ sylvestris (L.) Mill var. domestica (Borkh Mansf.))] yield or mean fruit weight was increased in seven of eight field studies by a particle film treatment (Glenn et al., 2001b). In these studies, increased photosynthesis was associated with reduced leaf temperature and increased

Received for publication 30 Aug. 2002. Accepted for publication 31 Jan 2003. The authors wish to thank the Washington State Tree Fruit Research Commission and the Engelhard Corporation for their financial support of this research. The efforts of Craig Cavin, USDA-ARS, and Alan Lakso, Cornell University, for the design and construction of the whole canopy chambers and measurement system are gratefully acknowledged. And for all their hard work, Frank Adams and Lee Carper, who organized the summer crew of Lola Popkins, Richard Ring, Julia Chandler, and Chad Alvarez, are sincerely thanked.

${ }^{1}$ Soil scientist; e-mail mglenn@afrs.ars.usda.gov.

${ }^{2}$ Horticulturist.

${ }^{3}$ Entomologist.

${ }^{4}$ Support scientist. stomatal conductance $\left(\mathrm{g}_{\mathrm{s}}\right)$ related to reduced heat stress. Glenn et al., (2001b) reviewed the studies of kaolin use and its effect on yield and water stress and concluded that the application of a reflective coating on plants under water stress provided more benefit in reducing the heat load than reduction in potential $\mathrm{A}_{\mathrm{CO}_{2}}$ due to light obstruction. Tworkoski et al., (2002) found that particle applications to bean plants did not affect $\mathrm{A}_{\mathrm{CO}_{2}}$ and bean leaf temperature was reduced but there was also a reduction in $\mathrm{g}_{\mathrm{s}}$ and transpiration $\left(\mathrm{E}_{\text {leaf }}\right)$, and an increase in the root:shoot ratio. The particle treatments also increased chlorophyll content of leaves, a typical shade response. However, Showler (2002) did not find evidence of a shade response in cotton when particle treatments were used, nor did he demonstrate an increase in cotton lint yield associated with PKPF treatments. Schupp et al., (2002) found that a PKPF reduced fruit size, red color, and sunburn in 'Fuji' apple in Idaho; while in New York, early season applications had no effect on fruit size or color in 'Honeycrisp', but late season applications reduced fruit size and red color. Jifon and Syvertsen (2003) demonstrated with citrus leaves that PKPF applications increased leaf reflectance, reduced midday leaf temperatures and leaf-to-air vapor pressure differences (VPD) compared to watersprayed control leaves. Midday reductions in leaf temperature and VPD were accompanied by increased $\mathrm{g}_{\mathrm{s}}$ and $\mathrm{A}_{\mathrm{CO} 2}$ of PKPF-treated leaves compared to control leaves. They demonstrated that the leaf water use efficiency of kaolin-treated leaves was higher than untreated leaves because $\mathrm{A}_{\mathrm{CO} 2}$ was increased without an increase in $\mathrm{E}_{\text {leaf }}$. Therefore, as in many biological systems, the response 
to microclimatic changes can vary depending on the specific environmental and biological conditions.

A wide range of minerals are available but only kaolin and calcium carbonate offer the low cost, safety profile, low abrasion, particle size, dispersibility in water, and general commercial availability needed for agricultural use. In the literature, calcium carbonate is not addressed as a reflective material for plants. This may be due to the reactive nature of the material with other agricultural chemicals and the plant itself, or the mineral may block too much light.

The entire plant needs to be evaluated in order to understand how a reflective film affects the energy and light budgets as well as the plant's response to these budgets. Enclosing entire plants, as compared to single leaves, and measuring $\mathrm{A}_{\mathrm{CO} 2}$ is a technique that provides whole plant information without the difficulties of extrapolation from single leaf measurements. Several whole-tree canopy $\mathrm{A}_{\mathrm{CO} 2}$ systems have been developed from the early work of Heinicke and Childers (1937) and are reviewed in Wünsche and Palmer (1997) and Whiting and Lang (2001). Whiting and Lang (2001) improved on these designs with a dispersing air delivery system that minimized systemic errors. The system of Wünsche and Palmer (1997) can provide continuous measurement of canopy $\mathrm{A}_{\mathrm{CO} 2}$ during the daylight and respiration at night; however, most systems are installed for a single day or short periods of time and so provide a temporal sampling of the plant's response to its environment or treatment. Discontinuous sampling of season-long whole plant responses requires interpolation of the plant response to nonmeasured periods of time in order to evaluate season-long responses. In modeled systems (Lakso, 1992), discontinuous temporal sampling can be used to validate models where the primary limiting factors are well defined, such as canopy light interception and $\mathrm{A}_{\mathrm{CO} 2}$.

Water use efficiency (WUE) can be measured instantaneously on a single leaf, for a single day in a whole canopy $\mathrm{A}_{\mathrm{CO} 2}$ chamber, or on a season-long basis. Isotopic discrimination of carbon-13 is a method of measuring season-long WUE.

Isotopic discrimination of carbon-13 has been correlated with WUE in field crops (Ehleringer, 1993; Farquhar and Richards, 1984; Farquhar et al., 1989; Johnson and Tieszen, 1993; LeRoux et al., 1996; Meinzer et al., 1993; White et al., 1990) and peach (Bongi et al., 1994; Glenn et al., 2000), and Jordan and Mariotti (1998) have used isotopic discrimination to describe the seasonal dynamics of carbon allocation in peach.

The purpose of our studies was to determine the effect of two processed-mineral particle film materials, based on processed kaolin and calcium carbonate, on whole plant carbon assimilation, water use efficiency, yield, fruit size and quality in 'Empire' apple over 4 years. Multiyear responses were evaluated to identify environmental conditions related to the treatment responses.

\section{Materials and Methods}

MAterials. Apple trees received applications of a highly reflective, white, hydrophilic particle based on kaolin mineral (Surround WP, Engelhard Corp., Iselin, N.J.) or ground calcium carbonate mineral (M97-005, Engelhard Corp., Iselin, N.J.) in addition to a conventional pesticide spray program. Both minerals are processed to a bright white color of $>90 \%$ reflectance, with mean particle size $<2 \mu \mathrm{m}$ in diameter. In 1998, a prototype of Surround WP (M97009) was used that varied only in the spreading and sticking agents. M97-005 was applied only in 1998 and 2000. The Surround WP, M97-009, and M97-005 treatments were prepared by adding the particles to water. The final mixture contained 6\% (w/v) in 1998 to 2000. In 2001, a 3\% mixture was applied. The Surround WP, M97-009, M97-005 and the conventional treatment were applied at the rate of $935 \mathrm{~L} \cdot \mathrm{ha}^{-1}(\approx 50 \%$ of tree row volume) using an air blast sprayer. Particle treatments were applied weekly for 6 weeks following petal fall and then every two weeks until harvest.

The apple orchard was a moderate density planting (500 trees/ha) of 'Empire'/M.7A planted in 1992 at the USDA-ARS Appalachian Fruit Research Station, Kearneysville, W.Va. The trees were not irrigated in 1998, 2000, and 2001. In 1999, trees were drip irrigated to meet the daily water needs. A separate group of trees were used in 1998 and 1999. The same trees were used in 2000 and 2001. In all years, the trees were hand-thinned post-bloom. Trees were treated with Surround WP, M97-005 or were not treated. All treatments were over-sprayed with conventional pesticides to protect from disease or insect damage. Conventional orchard practices were used in tree training and weed control. The experiment was a randomized block design with single tree plots in 1998, and four trees per plot for 1999 to 2001 with six replications. At harvest, all fruit were weighed and counted in each plot. Trunk diameters were measured yearly in the dormant season at a $30 \mathrm{~cm}$ height above the soil surface.

FrUIT QUALITY PARAMETERS. In all studies, fruit were harvested at optimum maturity for storage based on firmness, starch, and soluble solids concentration (SSC). Ten randomly selected fruit per plot were collected at harvest for quality evaluation. Firmness was determined using the McCormick fruit pressure tester (EFFEGI Corp., Italy) equipped with a 11.1-mm probe. External color was determined using the Commission Internationale d'Eclairage (CIE) $\mathrm{L}^{*}, \mathrm{a}^{*}, \mathrm{~b}^{*}$ color space coordinates. Hue angle was calculated from these data. Four measurements for color were made at $90^{\circ}$ intervals around the equatorial axis of each fruit. SSC was determined from an aliquant of expressed juice from a longitudinal slice from each of 10 fruit. SSC was measured with an Abbe type refractometer (10450, American Optical Scientific Instruments Div., Buffalo, N.Y.) with a sucrose scale calibrated at $20{ }^{\circ} \mathrm{C}$. Statistical analysis of hue angle was based on a randomized block design with six replications. Fruit weight was analyzed using analysis of covariance in a randomized complete block design using SAS (Statistical Analysis System, Cary, N.C. version 8). Fruit number per tree was the independent covariate since average fruit size is inversely related to the number of fruit on the tree. Adjusted treatment means were compared using PDIFF which compares least squares means from the analysis of covariance.

Tree CANOPY SURfaCe TEMPERATURE. Tree canopy surface temperature was measured using an IR thermometer (mdel 110; Everest Interscience, Tustin, Calif.) located above and $4 \mathrm{~m}$ north of the tree. About $7 \mathrm{~m}^{2}$ of the targeted tree canopy was in the IR thermometer's field of view. Air temperature was measured within the canopy at a 2-m height. Air and canopy data were collected every 2 min on 17 Aug. 1999 from one PKPF-treated tree and one untreated tree.

LEAF CHLOROPHYLL. Ten mature leaves were collected from the distal fifth to tenth leaf position for chlorophyll analysis in July of each year. Leaves were detached and placed on ice and frozen at $-80{ }^{\circ} \mathrm{C}$ within $30 \mathrm{~min}$ of removal. Chlorophyll was extracted by placing discs of known area in liquid $\mathrm{N}$ and crushing with a mortar and pestle. Acetone $(80 \%+20 \%$ water $)$ was added to the leaf tissue. Chlorophyll a and $\mathrm{b}$ and total chlorophyll were extracted and analyzed spectrophotometrically according to MacKinney (1941). Data were analyzed in a randomized complete block design. Treatment means were compared using Fisher's protected least significant difference (LSD), $P \leq 0.05$. 
CARbON-13 ISOTOPE Discrimination. About $2 \mathrm{~g}$ of dormant season buds were collected from each tree following the 1998 growing season, and 30 debudded shoots/tree of previous season shoots were collected in 1999 to 2001 . The tissue was dried at $60{ }^{\circ} \mathrm{C}$ for $72 \mathrm{HR}$, ground, and analyzed for carbon-13 content and carbon13 discrimination $(\Delta)$ by Isotope Services (Los Alamos, N.M.). Isotopic discrimination was calculated according to Farquhar et al.,(1989). The isotopic composition of carbon dioxide in air $(\delta$ ${ }^{13} \mathrm{C}_{\text {air }}$ ) was assumed to be -7.8 parts per thousand (Francey et al., 1995). Data were analyzed in a randomized complete block design by sampling date. Treatment means were compared using Fisher's protected least significant difference (LSD), $P \leq 0.05$.

WhOLE CANOPY CARBON ASSIMILATION CHAMBER. The whole canopy carbon assimilation chamber was constructed of $0.08 \mathrm{~mm}$ (3 mil) polyester film (Mylar Type D; Dupont, Wilmington, Del.). Six vertical panels were attached with Velcro tape to a circular top. The bottom was constructed from an oversized square of $0.15 \mathrm{~mm}$ (6 mil) polyethylene plastic that was rolled up with the Mylar sides and then clamped every $15 \mathrm{~cm}$. The bottom panel had a radial cut to insert the tree and was sealed with Velcro. The bottom panel was tied to the tree for a tight fit at a point immediately below the first scaffold branch, generally 30 to $50 \mathrm{~cm}$ above the soil. The top and bottom panels were $2.1 \mathrm{~m}$ in diameter and the vertical panels were $2.1 \mathrm{~m}$ high resulting in a volume of $7.5 \mathrm{~m}^{3}$.

A hoop-structure of 13-mm electrical conduit was erected over each tree. Four components of the structure were joined together at the apex of the tree and the four conduit legs were attached to steel rods, hammered into the soil at the perimeter of the tree. The mylar chamber was placed over the metal conduit structure. The vertical panels and the bottom panel were gathered and folded around the metal structure. The outlet port was a $30-\mathrm{cm}$ hole in the top panel.

Air was forced into the chamber with a one horsepower fan attached to a metal conduit with a cross-sectional area of $777 \mathrm{~cm}^{2}$. Five holes were drilled in the conduit to measure air velocity with a velometer (model 6000-P; Alnor Instruments, Skokie, Ill.) and ten $2.5-\mathrm{cm}$ positions at each sample port were measured at the beginning and end of the sampling period. The velocity data were averaged to calculate mass air flux. Air was forced into the chamber by inserting the conduit into the seam of two vertical panels and the bottom panel. The conduit was kept horizontal by elevating the fan and conduit housing. Leaf movement was visually assessed to insure no large eddies developed in the chamber. About three chamber volumes were exchanged per minute. Air temperature was measured with a shielded thermocouple hanging $\approx 30 \mathrm{~cm}$ into the chamber through the outlet port. Whole canopy net $\mathrm{CO}_{2}$ and $\mathrm{H}_{2} \mathrm{O}$ exchange was measured with an infrared gas analyzer (CIRAS-1; PP Systems, Haverhill, Mass.) from the difference in $\mathrm{CO}_{2}$ and $\mathrm{H}_{2} \mathrm{O}$ concentration between the inlet (reference) and the outlet (analysis) ports of each chamber. Equal lengths of tubing were inserted into the conduit and the outlet port, and the sampled air was drawn to the IRGA with a pump. Response time was 10 to $15 \mathrm{~s}$. The sampled air was blown into a cylinder that was sampled by the IRGA with its own sampling pumps. Multiple chambers were sampled sequentially every 10 min using a programmable controller(SDM-CD16AC; Campbell Scientific, Logan, Utah) that controlled solenoid valves on the reference and analysis tubes of each chamber. The controller was programmed and data collected with a datalogger (CR-7; Campbell Scientific, Logan, Utah).

Data were collected from 0900 to 1500 HR on the following dates: 30 June; 1, 14, 15, 19, and 26 July; and 2 and 3 Sept. 1999; 1 and 28 June, 27 July, and 23 Aug 2000; 5 and 14 June, 5 and 17 July, 9 Aug, and 5 Sept. 2001.
Following harvest in 2001, four of the trees sampled for whole canopy carbon assimilation on 5 Sept., were covered with a netting to capture all the leaves when they abscised. The leaves were collected and air-dried at $80{ }^{\circ} \mathrm{C}$ for $96 \mathrm{~h}$. At the time of sampling, a subsample of $\approx 3 \mathrm{~kg}$ fresh weight was separated, the leaf area was measured, and the ratio of air-dried weight:leaf area was calculated. This ratio was used to convert the total air-dried weight of each tree to total leaf area. Leaf area index was the quotient of the total leaf area divided by the area of the canopy shadow measured within $1 \mathrm{~h}$ of solar noon.

Particle density on the leaves was measured by washoff of four leaves/tree at each sampling and ranged from 300 to 500 $\mu \mathrm{g} \cdot \mathrm{cm}^{-2}$.

Light INTERCEPTION. Photosynthetically active radiation $(P A R)$ was measured at a weather station $\approx 1000 \mathrm{~m}$ from the measurement site with a quantum sensor (model 190SA; LI-COR, Lincoln, Nebr.). In addition, PAR interception by the tree canopy sampled for whole canopy gas exchange was measured with a line quantum sensor (LI-COR, Lincoln, Nebr.) within 1 h of solar noon, 1 to $2 \mathrm{~d}$ before or after sampling. Incoming $P A R$ was measured above the canopy and then the sensor was placed below the canopy at eight locations radiating from the trunk to the edge of the shadow cast by the canopy. Interception was the quotient of mean $P A R$ below the canopy divided by the incoming $P A R$. The average diameter of the canopy shadow was measured and total $P A R$ interception (moles $P A R$ per tree for the time period) was the product of canopy area $\left(\mathrm{m}^{2}\right) \times$ incoming $P A R\left(\mu \mathrm{mol} \cdot \mathrm{m}^{-2} \cdot \mathrm{s}^{-1}\right) \times$ interception (expressed as a fraction of 1$) \times$ period of sampling (seconds). $\mathrm{A}_{\mathrm{CO} 2}\left(\mathrm{CO}_{2} \mathrm{~g} /\right.$ tree) was analyzed using analysis of covariance in a randomized complete-block design for all years. Intercepted $P A R$ per tree was the independent covariate. Treatment means were compared using Fisher's protected least significant difference (LSD), $P \leq 0.05$.

PAR REFleCtANCE FROM THE TREe CANOPY. On 5 Sept. 2000, light reflectance above the canopy was measured with a diode array spectrometer (Unisys; PP Systems, Haverhill, Mass.) at every $2 \mathrm{~nm}$ from 400 to $700 \mathrm{~nm}$. Measurements were made \pm 30 min of solar noon under clear sky conditions. Six PKPF, calcium carbonate-treated, and untreated trees were measured in a randomized complete block sequence. Measurements were made from the south side of the tree to eliminate shadows in the measured canopy. The spectrometer has a fiber optic light guide with a $25^{\circ}$ field of view. The light guide was held $2 \mathrm{~m}$ from the canopy and viewed a $0.6 \mathrm{~m}^{2}$ area. A full sun scan was measured before and after each measurement using a white porcelain surface reflecting the incident radiation. Percentage of full sun was calculated at each measured wavelength as (measured bits of reflectance for the treatment tree/full sun bits $) \times 100$. Data were analyzed in a randomized complete block design $(n=6)$ for percentage of full sun at 400, 430, 500, 600, 662, and $700 \mathrm{~nm}$.

\section{Results and Discussion}

Fruit yield per tree varied with year and no treatment differences were indicated (Table 1). PKPF treatments had the largest fruit weight in all years and fruit size was significantly greater than the untreated control in 1999, 2000 and 2001 based on analysis of covariance (Table 1). Average fruit weight is inversely related to the number of fruit on a tree. Trees were hand-thinned to approximately the same fruit load but the treatment response can be refined with analysis of covariance that uses the number of fruit per tree as an independent, quantitative factor in the analysis. Analysis of covariance estimates the mean response (fruit weight) for the 
Table 1. Effect of particle film treatments on fruit weight of 'Empire' apples from 1998 to 2001.

\begin{tabular}{|c|c|c|c|c|c|c|c|c|c|c|c|c|}
\hline \multirow[b]{3}{*}{ Treatment } & \multicolumn{3}{|c|}{1998} & \multicolumn{3}{|c|}{1999} & \multicolumn{3}{|c|}{2000} & \multicolumn{3}{|c|}{2001} \\
\hline & & & Adjusted & & & Adjusted & & & Adjusted & & & Adjusted \\
\hline & $\begin{array}{c}\text { Yield } \\
(\mathrm{kg} / \text { tree })\end{array}$ & $\begin{array}{c}\text { Mean } \\
\text { fruit } \\
\text { size }(g)\end{array}$ & $\begin{array}{c}\text { mean } \\
\text { fruit } \\
\text { size }(\mathrm{g})\end{array}$ & $\begin{array}{c}\text { Yield } \\
(\mathrm{kg} / \text { tree })\end{array}$ & $\begin{array}{c}\text { Mean } \\
\text { fruit } \\
\text { size }(\mathrm{g})\end{array}$ & $\begin{array}{c}\text { mean } \\
\text { fruit } \\
\text { size }(\mathrm{g})\end{array}$ & $\begin{array}{c}\text { Yield } \\
(\mathrm{kg} / \text { tree })\end{array}$ & $\begin{array}{c}\text { Mean } \\
\text { fruit } \\
\text { size }(g)\end{array}$ & $\begin{array}{c}\text { mean } \\
\text { fruit } \\
\text { size }(\mathrm{g})\end{array}$ & $\begin{array}{c}\text { Yield } \\
(\mathrm{kg} / \text { tree })\end{array}$ & $\begin{array}{c}\text { Mean } \\
\text { fruit } \\
\text { size }(g)\end{array}$ & $\begin{array}{c}\text { mean } \\
\text { fruit } \\
\text { size }(g)\end{array}$ \\
\hline Untreated & $71.7 \mathrm{a}^{\mathrm{z}}$ & $111.2 \mathrm{ab}$ & $110.7 a^{y}$ & 40.3 & $138.6 \mathrm{~b}$ & $140.3 \mathrm{~b}$ & $35.3 \mathrm{a}$ & $116.9 \mathrm{~b}$ & $117.8 \mathrm{~b}$ & $97.1 \mathrm{a}$ & $131.6 \mathrm{a}^{(0.36)}$ & $131.4 \mathrm{~b}^{(0.09)}$ \\
\hline Surround WP & $82.9 \mathrm{a}$ & $120.3 \mathrm{a}$ & $117.2 \mathrm{a}$ & 38.1 & $164.0 \mathrm{a}$ & $162.2 \mathrm{a}$ & $36.9 \mathrm{a}$ & $124.3 \mathrm{a}$ & $125.3 \mathrm{a}$ & $100.1 \mathrm{a}$ & $133.9 \mathrm{a}$ & $134.1 \mathrm{a}$ \\
\hline Calcium carbonate & $80.8 \mathrm{a}$ & $99.3 \mathrm{~b}$ & $103.3 \mathrm{~b}$ & -- & -- & -- & $45.9 \mathrm{a}$ & $119.6 \mathrm{ab}$ & $117.7 \mathrm{~b}$ & -- & -- & -- \\
\hline
\end{tabular}

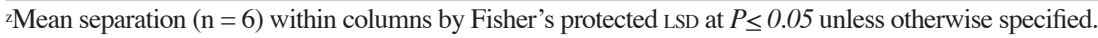

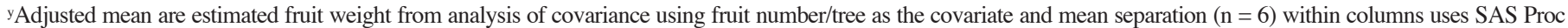
PDIFF at $P \leq 0.05$ unless otherwise specified.

mean number of fruit per tree. The small divergence of the mean from the adjusted mean is an indication that the distribution of fruit number per tree was similar within each year and for the treatments. In 1999, the response in increased fruit weight was the greatest of the 4 years, and the increased fruit weight was consistent over the range of fruit number per tree (Fig. 1). In 2001, the divergence of mean and adjusted means was the least of all years, yet the analysis of covariance indicated that additional variance was due to the number of fruit per tree and the level of significance changed from 0.36 to 0.09 . The regression of average fruit weight with fruit number per tree in 2001 indicates that at low fruit numbers, the weight of treated fruit was larger, but at the higher fruit numbers, the fruit weight is similar (Fig. 1). Fruit size of the calcium carbonate treatment was not different from the untreated control but was significantly lower than the PKPF treatment in both years based on the analysis of covariance (Table 1). Tree cross-sectional area was not affected by the treatments except in 2001 in which the PKPF treatment increased cross-sectional area compared to the control (11.5 vs. $18.5 \mathrm{~mm}^{2}$, untreated vs Surround WP in 2001, respectively).

Red color development in 'Empire' apple was increased in two of the four years by the PKPF treatment. In 1999 hue angles were 49.6 and 42.2 and in 2001 hue angles were 59.4 and 53.9 for untreated and Surround WP, respectively $(P \leq 0.05)$. In our previous studies with 'Empire' apple at Kearneysville, W.Va. (Glenn et al., 2001b), we found an increase in fruit weight and red color development with kaolin particle applications initiated in May or June and continued throughout the season, similar to the present studies.

'Empire' apple is considered a small-fruited cultivar (Schupp et al., 2002), and its fruit weight is very dependent on the crop load, as we have demonstrated (Fig. 1). Goffinet et al., (1995) found that thinning 'Empire' apples increased apple weight by allowing the remaining fruits to continue cell division during the first few weeks after bloom, rather than increasing cell size, or increasing the proportion of intercellular spaces in the fruit. Therefore, any environmental stress that reduces carbon allocation to the fruit during the cell division phase of fruit development will reduce fruit size, or conversely, any treatment that improves carbon allocation to the fruit will increase fruit size. Since our earlier work (Glenn et al., 2001b) and the 1998 study described in this work indicated consistent improvement in fruit weight with PKPF treatments in 'Empire' apples, we examined the variation in whole tree photosynthesis related to the use of particle films.

Whole canopy carbon assimilation was linearly related to $P A R$ interception by the tree (Fig. 2). Since the percentage of light interception for each tree was measured near solar noon, carbon assimilation from 1200 to $1400 \mathrm{HR}$ was calculated separately to determine if canopy PAR interception at noon was appropriate to use at times other than solar noon. From the pooled data for all three years, there was not a significant difference in the slope of the 1200 to 1400 HR data set compared to the 1000 to 1500 HR data set; however, the intercepts were different and were not negative as would be expected since the trees would respire in the dark. This is likely due to a nonlinear light response at low light levels that was not encountered in the field sampling. The difference in intercepts; however, does indicate that a single daily measurement of light interception is inadequate to describe the light interception of a tree with a canopy volume of $\approx 7 \mathrm{~m}^{3}$.

Analysis of covariance using intercepted $P A R$ as the covariate, indicated that within the three years, there were yearly and treatment effects on $\mathrm{A}_{\mathrm{CO} 2}$ (Table 2). In 1999, the PKPF treatment had greater $\mathrm{A}_{\mathrm{CO} 2}$ than the untreated control. There were no treatment differences in 2000 and 2001 however, 2000 had greater $\mathrm{A}_{\mathrm{CO} 2}$ than in 2001. Fruit weight analysis indicated that PKPF increased carbon partitioning to fruit in two of four years (Table 1); however, whole tree $\mathrm{A}_{\mathrm{CO} 2}$ only indicated that 1999 had a significant increase in $\mathrm{A}_{\mathrm{CO} 2}$. The increase in fruit weight in 1999 was the largest of the study and it is likely that whole canopy $\mathrm{A}_{\mathrm{CO} 2}$ measurements did not detect small cumulative effects when infrequently sampling tree performance. In addition, the mean monthly temperature of July 1999 was $\approx 4{ }^{\circ} \mathrm{C}$ higher than in 2000 or 2001. 1999 was a hot and droughty year that required irrigation but the excessive heat was likely a factor limiting $\mathrm{A}_{\mathrm{CO} 2}$ that the PKPF helped to mitigate. A

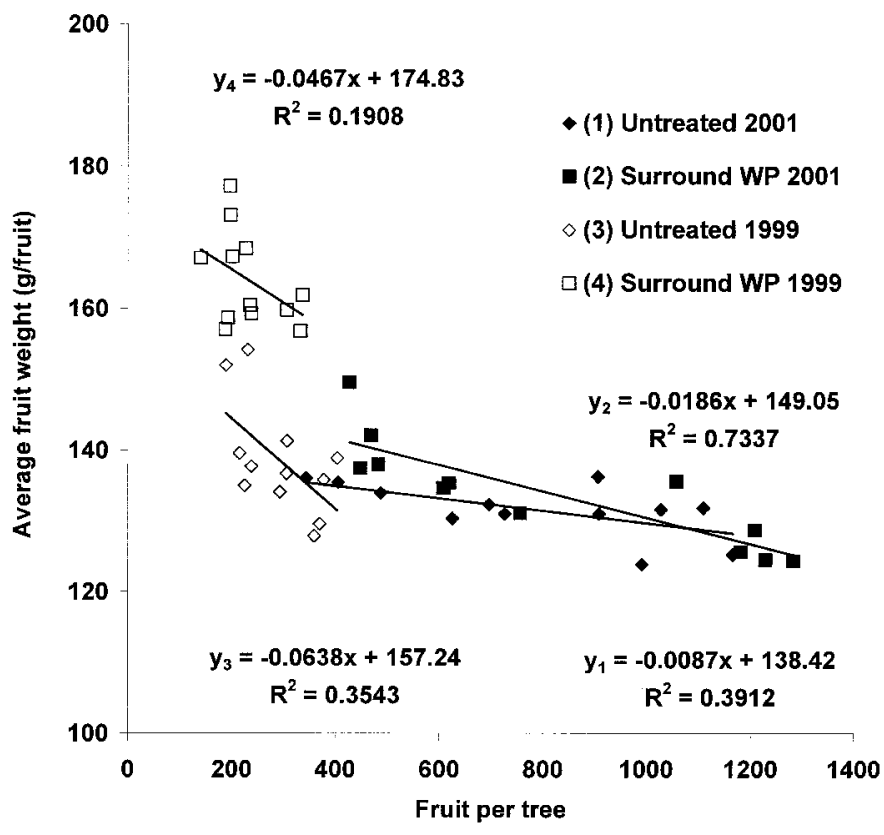

Fig. 1. Relationship between fruit weight and fruit number for Surround WPtreated and untreated 'Empire' apple trees in 1999 and 2001. 


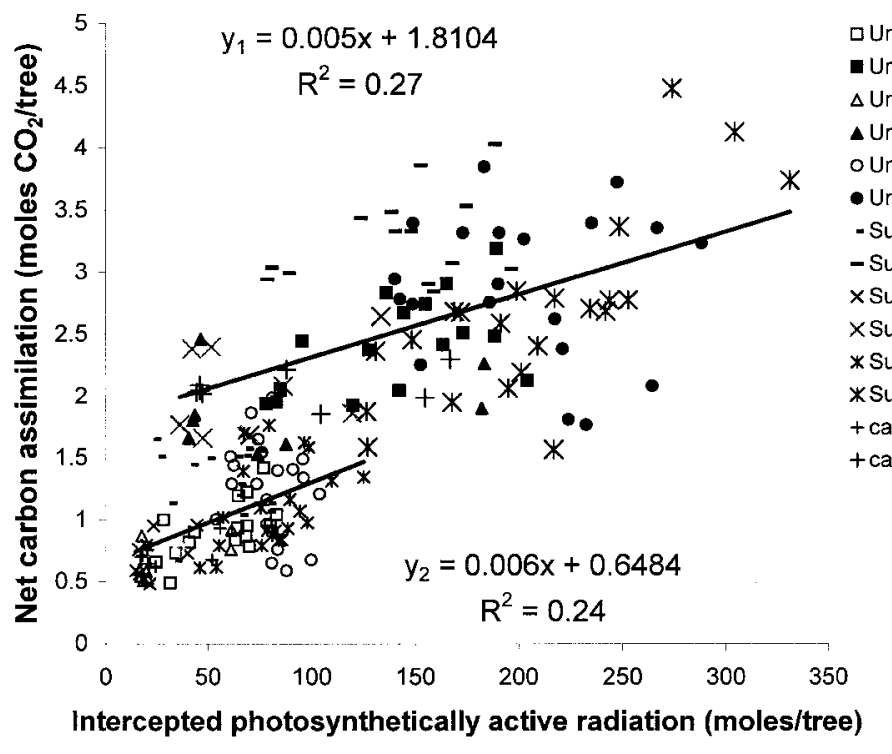

Fig. 2. Relationship between whole tree net carbon assimilation and intercepted photosynthetically active radiation for Surround WP- and calcium carbonatetreated and untreated 'Empire' apple trees in 1999, 2000 and 2001 at 1000 to $1500 \mathrm{HR}\left(\mathrm{y}_{1}\right)$ and 1200 to $1400 \mathrm{HR}\left(\mathrm{y}_{2}\right)$.

PKPF reduced fruit temperature (Glenn et al., 2002) and reduced canopy temperature (Fig. 3), which are key mechanisms of heat stress reduction. In 1999, five of the eight sampling dates occurred in July when heat stress was likely most severe, so the measurement of whole canopy $\mathrm{A}_{\mathrm{CO} 2}$ will detect large treatment differences, but likely there were brief periods of stress in 2000 and 2001 that were either not sampled or not detectable, but cumulatively, reduced carbon partitioning to the fruit in the control treatments, and the PKPF treatments mitigated these stresses to some extent because an increase in fruit weight was measured. An example of this situation is presented for 14 July 1999 (Fig. 4). Net carbon assimilation was similar from 0900 to $1000 \mathrm{HR}$ for the control and PKPF treatments, and after $1000 \mathrm{HR}, \mathrm{A}_{\mathrm{CO} 2}$ declined for the control treatment but remained relatively constant for the PKPF treatment. Water use was higher from 1000 to $1400 \mathrm{HR}$ and WUE was lower at $1000 \mathrm{HR}$ for the PKPF treatment compared with the control.

Water use efficiency declined with increasing solar radiation for all treatments and all years (Fig. 5). Jones (1976) demonstrated from field and modeling data that WUE declines with increasing incident radiation and $\mathrm{A}_{\mathrm{CO} 2}$. In addition, air temperature generally rises with $P A R$ and so the relationship is confounded by the interaction with temperature and possible heat stress effects. Analysis of covariance of WUE, using intercepted PAR as the covariate, indicated that there were treatment differences in some years (Table 2). The year 1999 had a low WUE with no treatment differences, while 2000 had the highest WUE with the PKPF treatment having significantly lower
WUE than the control or calcium carbonate. 2001 alsohad low WUEbut the PKPF treatment had significantly lower $(P \leq 0.10)$ WUE than the control. Isotopic discrimination of carbon-13 is an alternate technique to measure WUE and it integrates the entire growing season rather than short time periods. Water use efficiency is inversely related to $\Delta$ in tree fruit crops (Bongi et al., 1994; Glenn et al., 2000). Analysis of tissue carbon-13 content (Table 3 ) confirmed that the PKPF treatment had significantly higher $\Delta$ in 2 of 4 years and therefore, lower WUE in those years. Isotopic discrimination of carbon-13 occurs through two mechanisms: 1) physical fractionation through the stomatal opening, or 2) fractionation by carboxylation within the mesophyll cells (Farquhar and Richards, 1984). It is likely that physical fractionation is the dominant mechanism in these studies since PKPF increased fruit weight and growth and this must have occurred through increased $g_{s}$ leading to increased $\mathrm{A}_{\mathrm{CO} 2}$. The PKPF reduced canopy temperature, which would increase $g_{s}$ and $\mathrm{E}_{\text {leaf }}$, thereby increasing $\mathrm{CO}_{2}$ diffusion into the stomatal cavity resulting in increased $\mathrm{A}_{\mathrm{CO} 2}$ and fruit weight with a subsequent increase in water use, as shown in Fig. 5. The reduction of heat stress by PKPF would increase $g_{s}$, reduce carbon- 13 fractionation, and increase $\Delta$. Significant differences in isotopic discrimination in 1999 and 2000 occurred in the same years of the largest fruit size differences (Tables 1 and 3) supporting the concept that the PKPF reduced heat stress and increased stomatal conductance and $\mathrm{A}_{\mathrm{CO} 2}$. The inability to directly measure a difference in WUE in 1999 (Table 2) is most likely due to measurement variation pooled over the growing season, since on an individual day basis, there were events with reduced WUE (Fig. 5).

Leaf chlorophyll content was unaffected by the treatments in all years (data not presented) as we reported in previous work (Glenn et al., 2001b).

Following harvest in 2001, four of the trees sampled for whole canopy carbon assimilation on 5 Sept. were covered with a netting to capture all the leaves when they abscised to calculate leaf area and leaf area index. The carbon assimilation rates of the four trees were equivalent to whole plant assimilation rates in Angelonia angustifolia Benth. (Miller et al., 2001) and Magnolia grandiflora L. (van Iersel and Lindstrom, 1999) (Table 4). However, the rates were low compared to sweet cherry $\mathrm{A}_{\mathrm{CO} 2}$ rates of 10 to 20 $\mu \mathrm{mol} \cdot \mathrm{m}^{-2} \cdot \mathrm{s}^{-1}$ (Whiting and Lang, 2001) and Y-trellis peach $\mathrm{A}_{\mathrm{CO} 2}$ rates of 11 to $13 \mu \mathrm{mol} \cdot \mathrm{m}^{-2} \cdot \mathrm{s}^{-1}$ (Giuliani et al., 1998), but higher than delayed vasette and palmette trained peach tree $\mathrm{A}_{\mathrm{CO} 2}$ rates of 3 to $5 \mu \mathrm{mol} \cdot \mathrm{m}^{-2} \cdot \mathrm{s}^{-1}$ (Giuliani et al., 1998). These differences may be due to species and/or variation in the LAI or extreme leaf age at the end of the growing season. Giuliani et al.,(1998) demonstrated

Table 2. Effect of particle film treatments on whole tree carbon assimilation and water use efficiency from 1000 to 1500 HR for 3 years.

\begin{tabular}{|c|c|c|c|c|c|c|}
\hline \multirow[b]{2}{*}{ Treatment } & \multicolumn{3}{|c|}{$\begin{array}{l}\text { Mean carbon assimilation } \\
(\mathrm{mol} / \text { tree })\end{array}$} & \multicolumn{3}{|c|}{$\begin{array}{l}\text { Mean water use efficiency } \\
\left(\mu \mathrm{mol} \mathrm{CO} \mathrm{CO}_{2} / \mathrm{mmol} \mathrm{H}_{2} \mathrm{O}\right)\end{array}$} \\
\hline & 1999 & 2000 & 2001 & 1999 & 2000 & 2001 \\
\hline Untreated & $1.77 \mathrm{~b}^{\mathrm{z}}$ & $1.85 \mathrm{a}$ & $1.68 \mathrm{a}$ & $2.80 \mathrm{a}^{\mathrm{z}}$ & $4.64 \mathrm{a}$ & $2.84 \mathrm{a}$ \\
\hline Calcium carbonate & & $1.97 \mathrm{a}$ & & & $4.64 \mathrm{a}$ & \\
\hline
\end{tabular}

${ }^{z}$ Adjusted means are estimated net carbon assimilation or water use efficiency from analysis of covariance using intercepted $P A R$ as the covariate. Mean separation ( $\mathrm{n}=32,18$, and 46 for 1999,2000 , and 2001, respectively) within years used SAS Proc PDIFF over $P \leq 0.05$ unless otherwise specified. 


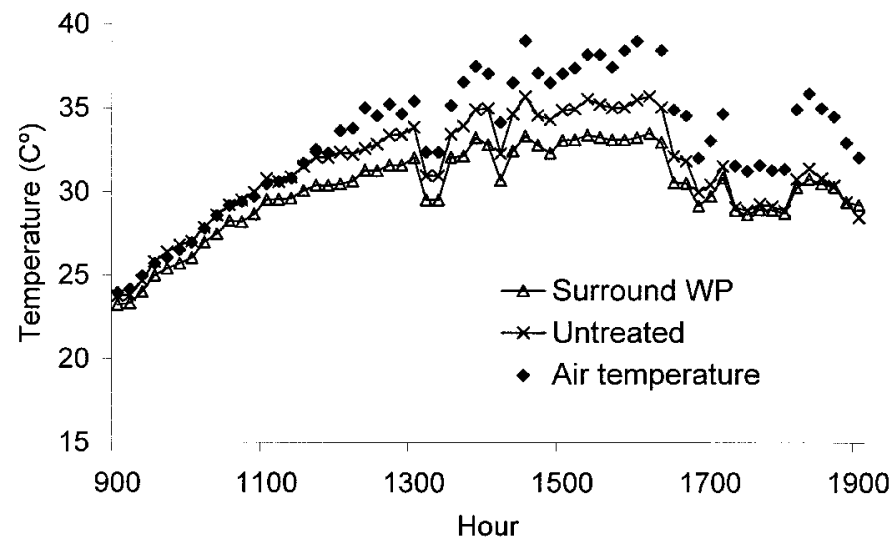

Fig. 3. Air and canopy temperature of Surround WP-treated and untreated trees on 17 August 1999.

that the Y-trellis training system intercepted more $P A R$ than the vasette or palmette systems with a consequent increase in carbon assimilation. A LAI of $>2.5$ (Table 4 ) is a dense canopy for fruit trees (Jackson, 1980) and likely resulted in extensive shading within the canopy which would reduce the whole canopy assimilation rate. Water use efficiency of 'Empire' apple (Table 2, Fig. 5) was similar to the WUE of peach (Giuliani et al., 1998), which ranged from 2 to $6 \mu \mathrm{mol} \mathrm{CO}_{2} / \mathrm{mmol} \mathrm{H}_{2} \mathrm{O}$ and apple (Green et al., 1995), which ranged from 2 to $4 \mu \mathrm{mol} \mathrm{CO} / \mathrm{mmol} \mathrm{H}_{2} \mathrm{O}$.

While both PKPF and calcium carbonate are reflective minerals, calcium carbonate does not demonstrate the potential to improve plant productivity or quality by reducing heat stress. An important reason for this lack of response is the greater reflection of $P A R$ from above the canopy (Fig. 6) and presumably excessive reduc-

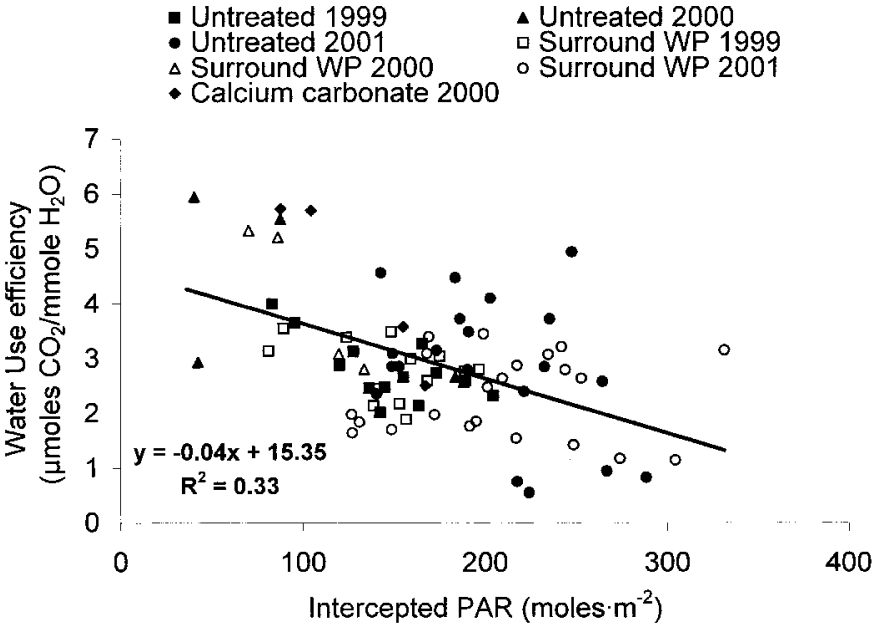

Fig. 5. Relationship between water use efficiency and intercepted photosynthetically active radiation for Surround WP- and calcium carbonate-treated and untreated 'Empire' apple trees in 1999, 2000, and 2001.

Table 3. Effect of particle film treatments on isotopic carbon-13 discrimination in 4 years.

\begin{tabular}{lcccc}
\hline & \multicolumn{4}{c}{ Isotopic discrimination $(\Delta)$ of carbon-13 } \\
\cline { 2 - 5 } Treatment & 1998 & 1999 & 2000 & 2001 \\
\hline Untreated & $19.4 \mathrm{a}$ & $17.7 \mathrm{~b}^{\mathrm{z}}$ & $19.5 \mathrm{~b}$ & $19.3 \mathrm{a}$ \\
Surround WP & $19.4 \mathrm{a}$ & $18.3 \mathrm{a}$ & $19.9 \mathrm{a}$ & $19.3 \mathrm{a}$ \\
Calcium carbonate & $19.6 \mathrm{a}$ & --- & $19.4 \mathrm{~b}$ & --- \\
\hline
\end{tabular}

${ }^{\mathrm{z}}$ Mean separation $(\mathrm{n}=6)$ within columns by Fisher's protected LSD at $P \leq 0.05$.
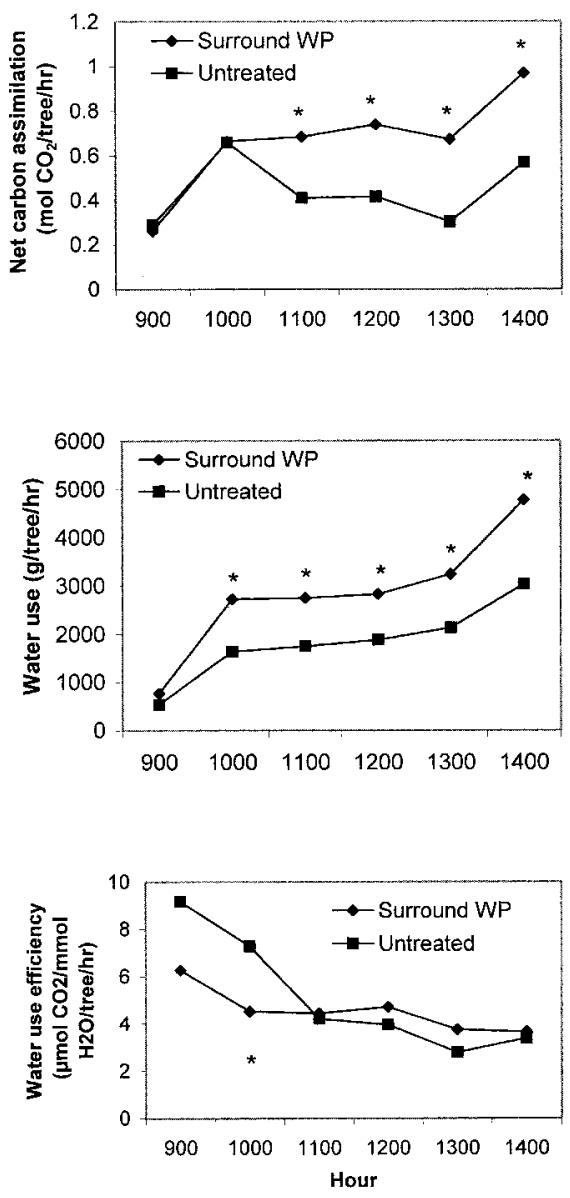

Fig. 4. Carbon assimilation (top), water use (middle), and wateruse efficiency (bottom) of Surround WP-treated and untreated trees on 14 July 1999. *Significant difference at $P \leq 0.10, \mathrm{n}=2$.

tion of PAR reaching the leaf.

In conclusion, the application of a PKPF reduced canopy temperature, and presumably reduced environmental stress, resulting in increased mean fruit weight and red color in 2 of 4 years of the study. Whole canopy $\mathrm{A}_{\mathrm{CO} 2}$ increased only under conditions of high air temperature. Increasing $\mathrm{A}_{\mathrm{CO} 2}$ by the PKPF treatment reduced WUE which was likely due to increased stomatal conductance associated with reduced leaftemperature. Calcium carbonate demonstrated none of these effects. Calcium carbonate reflected more PAR than the PKPF. In the use of particle films, there is an equilibrium between the nonproductive reflection of $P A R$ from the film and the productive reduction of leaf temperature that is determined by the particle film physical structure. It appears that the PKPF alters the equilibrium to favor the productive reduction of leaf temperature, rather than the nonproductive loss of light from the leaf. Calcium carbonate, however, demonstrates a neutral effect in which there is insufficient canopy cooling to compensate for the increased reflection of $P A R$. With this hypothesis, particle film applications in regions of cool temperatures would likely not respond or respond with reduced productivity, as Schupp et al. (2002) have demonstrated. However, in regions that experience heat stress, such as the mid-Atlantic states and semi-arid regions (Glenn et al., 2002), cultivars with heat stress intolerance, such as 'Empire', can be aided by the use of a PKPF.

\section{Literature Cited}

Bongi, G., A. Palliotti, P. Rocchi, and G. Roselli. 1994. Evaluation of WUE in peach grafted on different interspecific hybrid rootstocks. Plant Physiol. Biochem. 32:149-157.

Ehleringer, J.R. 1993. Variation in leaf carbon isotope discrimination in Encelia farinosa: Implications for growth, competition and drought survival. Oecologia 95:340-346.

Farquhar, G.D., J.R. Ehleringer, and K.T. Hubick. 1989. Carbon isotope discrimination and photosynthesis. Annu. Rev. Plant Physiol. Mol. Biol. 40:503-537.

Farquhar, G.D. and R.A. Richards. 1984. Isotopic composition of plant carbon correlates with water-use efficiency of wheat genotypes. Austral. J. Plant Physiol. 11:539-552.

Francey, U.J., P.P. Tans, C.E. Allison, I.G. Enting, J.W.C. White, and M. Troller. 1995. Changes in oceanic and terrestrial carbon uptake since 
Table 4. Leaf area, leaf area index, and mean carbon assimilation rate for particle film treated and untreated trees on 5 Sept. 2001.

\begin{tabular}{|c|c|c|c|c|c|}
\hline \multirow[b]{2}{*}{ Treatment } & \multirow[b]{2}{*}{ Tree } & \multirow{2}{*}{$\begin{array}{l}\text { Leaf area } \\
\qquad\left(\mathrm{m}^{2}\right)\end{array}$} & \multirow{2}{*}{$\begin{array}{c}\text { Leaf area } \\
\text { index }\end{array}$} & \multicolumn{2}{|c|}{$\begin{array}{l}\text { Carbon assimilation } \\
\left(\mu \mathrm{mol} \mathrm{CO} \mathrm{CO}_{2} / \mathrm{m}^{2} / \mathrm{s}\right)\end{array}$} \\
\hline & & & & $1200-1400 \mathrm{HR}$ & $1000-1500 \mathrm{HR}$ \\
\hline Untreated & 1 & 20.4 & 2.4 & 7.4 & 7.4 \\
\hline \multirow[t]{2}{*}{ Surround WP } & 1 & 19.5 & 2.6 & 6.4 & 6.7 \\
\hline & 2 & 26.5 & 2.5 & 6.5 & 7.1 \\
\hline
\end{tabular}

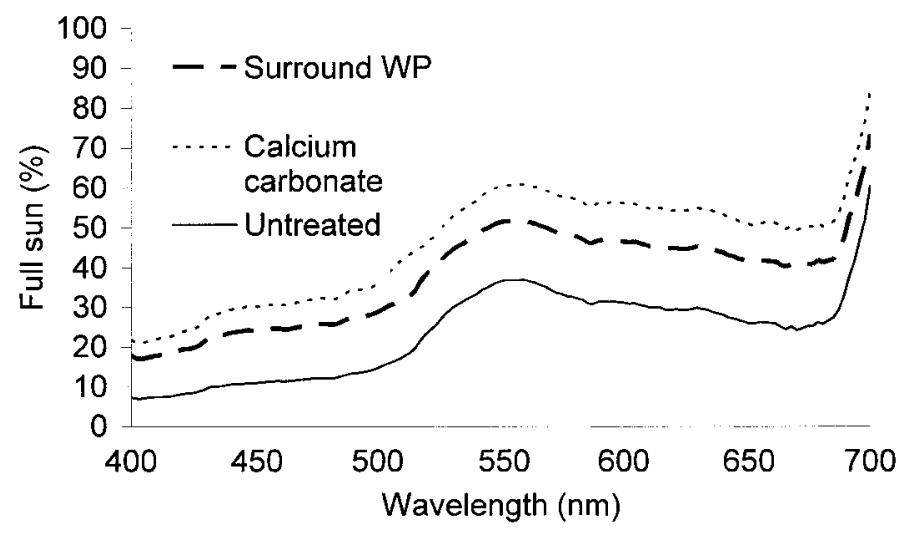

Fig. 6. Reflected light measured 2 m above the tree canopy for Surround WP-, calcium carbonate-treated, and untreated trees $(n=6)$. All treatments were significantly different from each other at 400, 430, 500, 600, 662, and $700 \mathrm{~nm}$.

1982. Nature 373:326-330.

Glenn, D.M., E. Prado, A. Erez, J. McFerson, and G.J. Puterka. 2002. Effect of a reflective, processed-kaolin particle film on fruit temperature, radiation reflection and solar injury in apple. J. Amer. Soc. Hort. Sci. 127:1-6.

Glenn, D.M., T. van der Zwet, G.J. Puterka, P. Gundrum, and E. Brown. 2001a. Efficacy of kaolin-based particle films to control apple diseases. Online. Plant Health Progress doi:10.1094/PHP-2001-0823-01-RS. <http: //www.plantmanagementnetwork.org>

Glenn, D.M., G.J. Puterka, S. Drake, T.R. Unruh, A.L. Knight, P. Baherle, E. Prado, and T. Baugher. 2001b. Particle film application influences apple leaf physiology, fruit yield and fruit quality. J. Amer. Soc. Hort. Sci. 126:175-181.

Glenn, D.M., G.J. Puterka, T. van der Zwet, R.E. Byers, and C. Feldhake. 1999. Hydrophobic particle films: A new paradigm for suppression of arthropod pests and plant diseases. J. Econ. Entomol. 92:759-771.

Glenn, D.M., R. Scorza, and C. Bassett. 2000. Physiological and morphological traits associated with increased water use efficiency in the willow-leaf peach. HortScience 35:1241-1243.

Goffinet, M.C., T.L. Robinson, and A.N. Lakso. 1995. A comparison of 'Empire' apple fruit size and anatomy in unthinned and hand-thinned trees. J. Hort. Sci. 70:375-387.

Green, S.R., K.G. McNaughton, D.H. Greer, and D.J. McLeod. 1995. Measurement of the increased $P A R$ and net all-wave radiation absorption by an apple tree caused by applying a reflective ground covering. Agr. For. Meteorol. 76:163-183.

Giuliani, R., E. Magnanini, L. Corelli-Grappadelli. 1998. Whole canopy gas exchanges and light interception of three peach training systems. Proc. 4th Intl. Peach Symp. Acta Hort 465:309-317.

Heinicke, A.J. and N.F. Childers. 1937. The daily rate of photosynthesis, during the growing season of 1935, of a young apple tree of bearing age. Cornell Univ. Agr. Expt. Sta. Mem. 201.

Jackson, J.E. 1980. Light interception and utilization by orchard systems. Hort. Rev. 2:208-267.

Jifon, J.L. and J.P. Syvertsen. 2003. Foliar sprays of kaolin clay can increase photosynthesis and water use efficiency of citrus leaves. J. Amer. Soc. Hort. Sci. 128:107-112.

Johnson, R.C. and L.L. Tieszen. 1993. Carbon isotope discrimination, water relations and gas exchange in temperate grass species and accessions, p. 281-296. In: J.R. Ehleringer, A.E. Hall, and G.D. Farquhar (eds.). Stable isotopes and plant carbon-water relations. Academic Press, San Diego, Calif.

Jones, H.G. 1976. Crop characteristics and the ratio between assimilation and transpiration. J. Appl. Ecol.13:605-622.

Jordan, M.O. and A. Mariotti. 1998. Can carbon isotopic discrimination in young peach trees be considered as a tool to understand the seasonal dynamic of the stored carbon? Acta Hort. 465:327-335.

Knight,A.L., T.R. Unruh, B.A. Christianson, G.J. Puterka, andD.M. Glenn. 2000. Effects of a kaolin-based particle film on obliquebanded leafroller (Lepidoptera:Tortricidae). J. Econ. Entomol. 93:744-749.

Lakso, A.N. 1992. The simplified dry matter production model for apple: Estimation of canopy photosynthesis in discontinuous canopies. Acta Hort. 313:45-52.

Le Roux, D., W.D. Stock, W.J. Bond and D. Maphanga. 1996. Dry mass allocation, WUE and $\delta^{13} \mathrm{C}$ in clones of Eucalyptus grandis, E. grandis $\times$ camaldulensis and $E$. grandis $\times$ nitrens grown under two irrigation regimes. Tree Physiol. 16:497-502.

MacKinney, G. 1941. Absorption of light by chlorophyll solutions. J. Biol. Chem. 140:315-322.

Meinzer, F.C., G. Goldstein, and D.A. Grantz. 1993. Carbon isotope discrimination and gas exchange in coffee during adjustiment to different soil moisture regimes, p. 327-345. In: J.R. Ehleringer, A.E. Hall, and G.D. Farquhar (eds.). Stable isotopes and plant carbon-water relations. Academic Press, San Diego, Calif.

Miller, A.M., M.W. van Iersel, and A.M. Armitage. 2001. Whole-plant carbon dioxide exchange responses of Angelonia angustifolia to temperature and irradiance. J. Amer. Soc. Hort. Sci. 125:606-610.

Puterka, G.J., D.M. Glenn, D.G. Sekutowski, T.R. Unruh, and S.K. Jones. 2000. Progress toward liquid formulations of particle films for insect and disease control in pear. Environ. Entomol. 29:329-339.

Schupp, J. R., E. Fallahi, and I. Chun. 2002. Effect of particle film on fruit sunburn, maturity and quality of 'Fuji' and 'Honeycrisp' apples. HortTechnology 12:87-90.

Showler, A.T. 2002. Effects of kaolin particle film on beet armyworm, Spodoptera exigua (Hubner) (Lepidoptera: Noctuidae), oviposition and larval feeding and development on cotton, (Gossypium hirsutum L.). Agr. Ecosys. Environ. (in press).

Tworkoski, T.J., D.M. Glenn, and G.J. Puterka. 2002. Response of bean to applications of hydrophobic mineral particles. Can. J. Plant Sci. 82: 217-219.

Unruh, T.R., A.L. Knight, J. Upton, D.M. Glenn, and G.J. Puterka. 2000. Particle films for suppression of the codling moth (Lepidoptera:Tortricidae) in apple and pear orchards J. Econ. Entomol. 93:737-743.

van Iersel, M.W. and O.M. Lindstrom. 1999. Temperature response of whole-plant $\mathrm{CO}_{2}$ exchange rates of three magnolia cultivars. J. Amer. Soc. Hort. Sci. 124:277-282.

White, J.W., J.A. Castillo, and J. Ehleringer. 1990. Associations between productivity, root growth and carbon isotope discrimination in Phaseolus vulgaris under water deficit. Austral. J. Plant Physiol. 17:189-198.

Whiting, M.D. and G.A. Lang. 2001. Canopy architecture and cuvette flow patterns influence whole-canopy net $\mathrm{CO}_{2}$ exchange and temperature in sweet cherry. HortScience 36:691-698.

Wünsche, J.N. and J.W. Palmer. 1997. Portable through-flow cuvette system for measuring whole-canopy gas exchange of apple trees in the field. HortScience 32:653-658. 